\title{
Article \\ The Implementation Factors of Information and \\ Communication Technology in the Life Cycle Costs of Buildings
}

\author{
Peter Mésároš ${ }^{1}$, Tomáš Mandičák ${ }^{1, *} \mathbb{0}$, Marcela Spišáková ${ }^{1}$, Annamária Behúnová ${ }^{2} \mathbb{D}$ and Marcel Behún ${ }^{2}$ \\ 1 Institute of Technology, Economics and Management in Construction, Faculty of Civil Engineering, Technical \\ University of Košice, 04200 Košice, Slovakia; peter.mesaros@tuke.sk (P.M.); marcela.spisakova@tuke.sk (M.S.) \\ 2 Institute of Earth Sources, Faculty of Mining, Ecology, Process Control and Geotechno-Logy, \\ Technical University of Košice, 04001 Košice, Slovakia; annamaria.behunova@tuke.sk (A.B.); \\ marcel.behun@tuke.sk (M.B.) \\ * Correspondence: tomas.mandicak@tuke.sk; Tel.: +421-55-602-4378
}

check for updates

Citation: Mésároš, P.; Mandičák, T.; Spišáková, M.; Behúnová, A.; Behún, M. The Implementation Factors of Information and Communication Technology in the Life Cycle Costs of Buildings. Appl. Sci. 2021, 11, 2934. https://doi.org/ 10.3390/app11072934

Academic Editors: Alberto Benato and Edyta Plebankiewicz

Received: 4 February 2021

Accepted: 23 March 2021

Published: 25 March 2021

Publisher's Note: MDPI stays neutral with regard to jurisdictional claims in published maps and institutional affiliations.

Copyright: (c) 2021 by the authors. Licensee MDPI, Basel, Switzerland. This article is an open access article distributed under the terms and conditions of the Creative Commons Attribution (CC BY) license (https:// creativecommons.org/licenses/by/ $4.0 /)$.

\begin{abstract}
Life cycle cost management is an integral part of buildings construction. The life cycle cost approach can be considered an objective approach because it considers all life cycles of buildings. Information and communication technology is one of the critical factors for the success of construction projects. Several studies point to the importance of information and communication technology use in life cycle cost management. Generally, information and communication technology can be helpful in the cost management process of buildings. However, few implementation factors of information and communication technology are used in the life cycle cost management of buildings. The research assumes that the most critical implementation factor is the investment cost for information and communication technologies used in cost management during the life cycle. The relative importance index method was used to evaluate and quantify the final rank of implementation factors. The Kruskal-Wallis test was used to confirm or reject research results that were statistically significant.
\end{abstract}

Keywords: implementation factors; information and communication technology; life cycle costs; buildings

\section{Introduction}

The issue of cost optimization is topical, particularly when participants in construction projects strive to reduce costs from the life cycle cost perspective. The construction project should consider cost management approaches from the buildings' whole life cycle perspective. Life cycle cost management plays an important role that focuses on cost optimization [1]. However, this approach has more potential for use than is currently utilized. This is because the relevant databases of information on the expected lifetime of buildings, the time and extent to which they require repairs, and the structures' maintenance costs are not available. According to Biolek and Hanák [2], these data should be processed in future building information modeling (BIM) systems. Several authors have specified the so-called life cycle cost (LCC) [3]. This is mainly the sum of costs during the construction project's individual stages, such as ownership, implementation, maintenance, and liquidation of the building. Budgetary constraints, environmental conditions, lack of communication, and skilled labor availability affect costs and time, even during the maintenance phase. These factors can also significantly affect the cost-effectiveness and efficiency of design management and the construction phase. This means that there is a close link between the maintenance phase and the design and construction phase. Therefore, if the building fabric's maintenance can be related to the initial stage of the design and construction phase, textile maintenance plans can be planned, and compelling predictions of uncertainties can minimize textile maintenance costs [4]. 
Knezovic et al. [5] noted the application of artificial neural networks, and the specific advantages and disadvantages that characterize econometric models. Further research indicates that life cycle management (LCM) is a concept that is often seen as an aggregation of life cycle tools and methods, and focuses on minimizing environmental impacts throughout their life cycle. Overall, the life cycle costs of a given project have also been plotted [6-8]. Kambanou notes that this method is still not widespread and has more potential [9]. Perceiving a construction project as a business plan to optimize the life cycle cost is one way to achieve efficiency [10,11]. In addition, cost management has been examined via information and communication technology [11]. Other authors agree that the building project should be assessed in terms of its entire life cycle, including the project's cost [2]. A construction project's business success depends largely on accurate estimates, such as the initial investment costs from the design phase to the construction phase, the operating costs required for the operation and maintenance phases, and the profits accumulated during the operation phase [12]. In many cases, relevant socio-economic benefits and costs also affect the construction project's economic efficiency; the influence of these factors cannot be neglected [12]. According to other studies, operating costs exceed implementation [13]. This also applies to the assumption of energy utilization [14].

In connection with cost management, several authors have mentioned information technologies used for the needs of cost management. The use of information and digital technologies increases when more cost-effective applications are found [15]. Generally, it can be said that information technology is gradually expanding in the field of construction. Several scientists have specified the relationship between information and communication technology in the context of successful construction project management or cost management. Building costs commonly occur under various market and legal conditions, which, unfortunately, often negatively influence construction project aims. Numerous research results indicate the scale of this problem. It is possible to define different construction investments that can be specified in various stages of their implementation [16,17]. Investment projects are complex and require appropriate management at all stages. The importance of procurement is due to the main criteria that affect the project's success: cost, quality, time, safety, and how the project meets its envisaged purpose. For this reason, one of the crucial success factors of construction projects is to allow bidding for the contract only by contractors who are sufficiently qualified for the proper performance of that contract [18]. The different life cycles of construction projects can specify various types of investments. These are characterized by different technological, organizational, and economic specifications [19]. There are specific costs associated with repairing defects. Knowledge about implementation factors and defects occurring in residential buildings can be used to better plan the investment budget [20].

Several studies have already partially addressed factors in implementing information and communication technology (ICT) for cost management or construction. Several studies suggest that these are investment costs [21-28]. A detailed overview of studies on this issue and the identification of factors is given in Table 1.

Table 1. Literature review of information and communication technology (ICT) implementation factors in the construction industry [21-32].

\begin{tabular}{|c|c|c|}
\hline Year & Implementation Factors & Relevant Literature \\
\hline 2020 & $\begin{array}{ll}\text { - } & \text { mimetic pressure, } \\
\text { - } & \text { strategic value judgment, } \\
\text { - } & \text { behavioral control capability }\end{array}$ & [24] \\
\hline 2019 & $\begin{array}{l}\text { - } \quad \text { communication and work relationship, } \\
\text { - } \quad \text { distraction and waste of time, } \\
\text { - better information management on-site, } \\
\text { - improved work planning }\end{array}$ & [22] \\
\hline
\end{tabular}


Table 1. Cont.

\begin{tabular}{|c|c|c|}
\hline Year & Implementation Factors & Relevant Literature \\
\hline 2019 & $\begin{array}{l}\text { - ICT human capital skills, } \\
\text { - } \quad \text { firm's decision-making process and support of visionary leaders, } \\
\text { - inter-organizational research and development collaboration }\end{array}$ & [29] \\
\hline 2018 & $\begin{array}{ll}- & \text { ICT safety, } \\
- & \text { investment costs, } \\
\text { - } & \text { people acceptance } \\
\text { - } & \text { support management }\end{array}$ & [21] \\
\hline 2017 & $\begin{array}{l}\text { - lack of understanding about the process of sensing technology adoption, } \\
\text { - } \quad \text { its purpose of utilization in construction industry }\end{array}$ & [30] \\
\hline 2012 & $\begin{array}{l}\text { - } \quad \text { investment costs, } \\
\text { - } \quad \text { lack of finance, } \\
\text { - } \quad \text { maintenance costs, } \\
\text { - lack of management support, } \\
\text { - } \quad \text { rejection of changes, } \\
\text { - } \quad \text { compatibility problems, } \\
\text { - law framework, } \\
\text { - } \quad \text { transparency and ICT safety, }\end{array}$ & [23] \\
\hline 2012 & $\begin{array}{l}\text { - } \quad \text { costs, } \\
\text { - } \quad \text { experiences, } \\
\text { - IT safety, }\end{array}$ & [25] \\
\hline 2011 & $\begin{array}{l}\text { - } \quad \text { high investment costs for ICT, } \\
\text { - } \quad \text { virus infiltration and degradation give, } \\
\text { - } \quad \text { cecurity and privacy, } \\
\text { - } \quad \text { increased IT staff costs, } \\
\text { - } \quad \text { incompatibility of product solutions, } \\
\text { - } \quad \text { poor return on investment, } \\
\text { - } \quad \text { personal abuse of ICT employees } \\
\text { - } \quad \text { weak management support }\end{array}$ & [31] \\
\hline 2009 & $\begin{array}{l}\text { - } \quad \text { investments, } \\
\text { - IT safety, }\end{array}$ & [28] \\
\hline 2008 & $\begin{array}{l}\text { - } \quad \text { investment costs, } \\
\text { - } \quad \text { human resources, } \\
\text { - } \quad \text { IT equipment }\end{array}$ & [26] \\
\hline 2007 & $\begin{array}{l}\text { - } \quad \text { diversity of construction industry, } \\
\text { - } \quad \text { construction project participants cooperation }\end{array}$ & [27] \\
\hline 2007 & $\begin{array}{l}\text { - } \quad \text { hardware and software costs, } \\
\text { - } \quad \text { concerns about virus infiltration, } \\
\text { - } \quad \text { ICT equipment, } \\
\text { - } \quad \text { return on investment, } \\
\text { - } \quad \text { fear of dismissing redundant workers, } \\
\text { IT security. }\end{array}$ & [32] \\
\hline
\end{tabular}

Information and communication technology includes, in particular, software applications designed for communication, working with data, and information sharing. A lack of confidence is observed among project stakeholders in the documented data's authenticity and integrity [33]. Cost savings, revenues, and improvements in the quality of construction projects increase the practice's credibility and convince potential project participants of these technologies' benefits [34]. Several studies point to some of the benefits of using 
information technology in cost management [35]. Cost savings were seen as the most significant benefit by Marsh and Flanagan [36]. Increased efficiency and increased transparency, and greater convenience in the procurement process were determined in the research by Khayyat [37]. ICT functionalities mainly relate to construction management, so it can be argued that the integration of a lean management approach with the technical capabilities of ICT will bring benefits to the overall productivity and efficiency of construction projects [38]. Another study examined the impact of ICT on the so-called operational benefits [39]. In this group of benefits, the authors included flexibility in systems to meet clients' needs; strengthening the relationship with suppliers; competitive advantage in economies of scale; shortening the production phase; and flexibility of response to the client.

In contrast, information technologies provide little or no benefit according to previous research [27]. However, this study argues that there are areas where information technology implementation can also be beneficial. Improved monitoring and control have also been identified as crucial in implementing ICT in construction due to the impact on cost management $[40,41]$. Other authors discussed the methods of measuring the benefits of ICT and BIM technologies in construction [42,43].

Concerning research on the life cycle cost of building and cost management in general, costs and investments can be highlighted as factors mentioned. An analysis of the implementation factors of ICT and subsequent quantification has not yet been carried out in any research found and included in the review. In particular, in life cycle cost management, it is appropriate to examine and verify the relationship of implementation factors in terms of cost optimization, and whether it is a dimension in the management of construction projects or life cycle cost management of construction projects. The research's basic scientific questions were determined based on theoretical overviews in the given area and a summary of this research. What are the implementation factors of ICT in life cycle cost management? The fundamental research problem is that investment costs are the most critical ICT implementation factor in building life cycle cost management.

Based on the literature, interviews with experts (project managers, cost managers, etc.), and formulation of the research problem, four categories of implementation factors were determined, in which the expected implementation factors were defined to be examined in the survey. These implementation factors were first discussed with selected practitioners. Their comments and expert advice were taken into account for the final formulation of implementation factors. This pre-research ensured a strict selection and formulation of implementation factors. Cronbach's alpha was also used to test these questions for the selection of these factors. Implementation factors that were not considered appropriate by the experts were not further investigated. Table 2 shows all research implementation factors. The most important of the these is the first factor (Investment costs of ICTs) from the research hypothesis's point of view. 
Table 2. Research ICT implementation factors in the construction industry (based on literature review and expert statements).

\begin{tabular}{|c|c|c|c|}
\hline Group of IF & Implementation Factors (IF) & & Description of Factors and Impact on LCC \\
\hline Economic factors & $\begin{array}{l}\text { 1. Investment costs for ICTs } \\
\text { 2. System maintenance costs during its lifetime } \\
\text { 3. The need to recruit IT staff to manage ICT }\end{array}$ & 2. & $\begin{array}{l}\text { Investment costs represent all costs related to the } \\
\text { implementation of information and } \\
\text { communication technologies, infrastructure } \\
\text { modification and all installation costs. Their } \\
\text { impact represents an increased cost of acquiring } \\
\text { the system in the first year, and ICT should have a } \\
\text { lower cost in the later period. } \\
\text { System maintenance costs represent all costs for } \\
\text { technology maintenance, upgrades, improvements, } \\
\text { and additional equipment management and } \\
\text { service costs. The level of these costs should be } \\
\text { lower than the cost savings resulting from ICT } \\
\text { implementation in each life phase of a construction } \\
\text { project. } \\
\text { Wage-related costs for new staff needed to manage } \\
\text { ICT. This factor represents the cost burden during } \\
\text { the entire construction period or each life cycle } \\
\text { stage of the construction project. }\end{array}$ \\
\hline
\end{tabular}

4. Ensuring the compatibility of technologies is challenging, especially in the construction project's design stage, where it is necessary to combine all technologies to ensure a smooth flow of data between devices. This can have a significant positive effect on other life cycle costs.

5. The functions and possibilities of technologies can be a motivation for implementation. It should have a positive impact on costs at each stage, especially concerning increasing productivity.

$\begin{array}{lll}\text { Technical factors } & \text { 6. } & \text { Knowledge of the use of ICT in the field } \\ & \text { 7. System maintenance and service and the need to }\end{array}$

Compatibility of software solutions

Functional possibilities of the system upgrade the system (administrative burden, inspections, repairs)

6. Knowledge is one of the prerequisites for the successful implementation of ICT. Their impact on LCC depends on the value of the people who have this knowledge and their ability to work with new ICTs, which reduces costs at every stage of the project.

7. The need to deal with service and constant upgrade is associated with increased costs and loss of time and energy of employees, which again has a negative impact on LCC.

8. From the LCC's point of view, the education and training of employees is a cost. The highest rate is at the beginning of the project, when this level is the highest.

9. Practical user experience can have a positive impact on LCC. Experience and the necessary qualifications represent a lower precondition for the need for training costs at each stage.

8. User qualification (training and certificates)

9. User experience (practical experience)

Personnel factors

10. Readiness and disinterest of users

11. Ability to embrace innovation and change

12. Management support

10. User lack of interest can have a serious negative impact on LCC. Their reluctance to accept change and innovation can lead to ever-increasing costs.

11. The reluctance to accept changes is equally negatively transmitted to the LCC.

12. Management support should be one of the keys in motivating new technologies to be adopted. The attitude of management can influence the opinion of employees on new technologies. This can have a positive effect on LCC of buildings. Management support can represent a high degree of ICT implementation and thus lead to cost savings at each stage. 
Table 2. Cont.

\begin{tabular}{|c|c|c|c|c|}
\hline Group of IF & & Implementation Factors (IF) & & Description of Factors and Impact on LCC \\
\hline Industry factors & $\begin{array}{c}13 . \\
14 . \\
15 . \\
16 .\end{array}$ & $\begin{array}{l}\text { Fragmentation of the sector and integration among } \\
\text { participants in construction projects } \\
\text { Legislative framework } \\
\text { Level of competition in the use of ICT } \\
\text { Level of use of ICT by other participants in the } \\
\text { construction project. }\end{array}$ & 15. & $\begin{array}{l}\text { Fragmentation of the sector and integration } \\
\text { between participants in construction projects } \\
\text { means a hard way of communication between } \\
\text { participants and increases misunderstandings. In } \\
\text { LCC, it is reflected as a negative phenomenon, with } \\
\text { a large number of sub-suppliers increasing costs } \\
\text { and expanding the supply chain. From the LCC } \\
\text { point of view, it is primarily the risk of increased } \\
\text { costs in the design and construction stage. On the } \\
\text { contrary, the use phase does not pose this risk. } \\
\text { The legislative framework may also affect the } \\
\text { implementation of ICT. If the legislation is simple } \\
\text { and fixed, it can lead to the facilitation of the whole } \\
\text { implementation process. On the contrary, if the } \\
\text { legislative framework is set incorrectly, a number } \\
\text { of restrictions, etc. this leads to a negative impact. } \\
\text { Legislation can also directly affect the regulation of } \\
\text { the use of specific ICT (such as BIM technology) in } \\
\text { the procurement process and in selected projects. } \\
\text { This may delay earlier implementation of ICT. This } \\
\text { can have a positive impact on LCC. Thus, costs can } \\
\text { decrease over time. } \\
\text { The level of use of ICT by competitors may impact } \\
\text { the decision of other construction companies to use } \\
\text { technology. To minimize LCC and increase } \\
\text { competitiveness, it also has this impact. } \\
\text { Other participants can pressure the use of selected } \\
\text { ICTs, which can be a motivator for rapid } \\
\text { implementation. To call other participants can } \\
\text { have a significant positive impact on the LCC. }\end{array}$ \\
\hline
\end{tabular}

\section{Materials and Methods}

\subsection{Research Methods and Steps}

This research consisted of two phases, the pre-research and the research. The preresearch included determining a basic research question based on a detailed theoretical analysis of previous research. This analysis also provided the basis for identifying implementation factors and grouping. These compiled implementation factors were discussed by relevant experts. Four project managers from large international construction companies discussed the proposed research implementation factors in an interview. Based on the agreement of all, the final implementation factors were determined, and were the subject of the investigation.

The selection of the research sample was based on the structure of the industry. The respondents' selection was from the building industry database (The Statistical Office of the Slovak Republic). The total number of entities in the construction industry in Slovakia is $83,560,000$. More than 1200 (sample file size) construction companies were approached to participate in construction projects and final buildings. Respondents were selected as a percentage composition reflecting the number of market participants. The statistical set of respondents included various participants in construction projects. The ratio of real business entities was maintained. Companies were contacted (investors $11.20 \%$, suppliers $52 \%$, sub-contractors $16.80 \%$, and designers $20 \%$ ), and 125 respondents took part in the survey. The return rate was $10.42 \%$.

Cronbach's alpha verified the suitability of the questions. This ensured an adequate distribution of the research sample. Data processing was based on the relative importance index and five critical levels method. Based on this, the ranking was determined, and the Kruskal-Wallis test for statistical significance was used to verify the results.

Subsequently, for quantification purposes, the selected group's arithmetic means and the specific factor were determined. The Kruskal-Wallis test was also used to verify the influence of a given factor. A detailed overview of the research steps and methods used is given in Table 3. 
Table 3. Research methods and steps.

\begin{tabular}{|c|c|c|c|c|}
\hline \multicolumn{5}{|c|}{ Pre-Research Stage } \\
\hline \multicolumn{2}{|c|}{ Research Steps } & Data Source & Methods & Results \\
\hline 1. & $\begin{array}{l}\text { Analysis of previous } \\
\text { research and creation of an } \\
\text { overview }\end{array}$ & Web of Science database & Analysis and synthesis & $\begin{array}{l}\text { Implementation factors of ICT in } \\
\text { LCC overview }\end{array}$ \\
\hline 2. & $\begin{array}{l}\text { Determination of research } \\
\text { question and hypothesis }\end{array}$ & Web of Science database & Analysis and synthesis & $\begin{array}{l}\text { Problem statement and } \\
\text { hypothesis }\end{array}$ \\
\hline 3. & $\begin{array}{l}\text { Analysis of implementation } \\
\text { factors-assessment of the } \\
\text { correctness of } \\
\text { implementation factors by } \\
\text { experts (construction } \\
\text { project managers by large } \\
\text { enterprises) }\end{array}$ & Primary data & Interview & $\begin{array}{l}\text { Selection of researched } \\
\text { implementation factors of ICT in } \\
\text { LCC-Final implementation } \\
\text { factors of ICT in LCC overview }\end{array}$ \\
\hline
\end{tabular}

Research steps

Research sample was performed at random. However, the research groups and their representation (number) were established

4. Selection of research sample Statistical Office database according to the number in the Research sample market. Thus, no research group was disadvantaged, and the research sample reflected the real market presence.

\begin{tabular}{|c|c|c|c|c|}
\hline 5. & Data collection & Questionnaire data & Likert scale & Research data \\
\hline 6. & Data processing & Questionnaire data & & \\
\hline (a) & $\begin{array}{l}\text { Evaluation of the suitability } \\
\text { of the questions asked }\end{array}$ & Questionnaire data & Cronbach's alpha & \\
\hline (b) & $\begin{array}{l}\text { Ranking of implementation } \\
\text { factors }\end{array}$ & Questionnaire data & $\begin{array}{l}\text { Relative importance index and } \\
\text { five critical levels }\end{array}$ & Ranking \\
\hline (c) & $\begin{array}{l}\text { Verification of ranking } \\
\text { results by statistical } \\
\text { significance }\end{array}$ & $\begin{array}{l}\text { Questionnaire data-Statistica } \\
\text { software }\end{array}$ & Kruskal-Wallis test & Statistical significance \\
\hline (d) & $\begin{array}{l}\text { Quantification of the ICT } \\
\text { implementation factors on } \\
\text { LCC }\end{array}$ & Questionnaire data & Arithmetic mean and impact rate & $\begin{array}{l}\text { Proposal of the influence of ICT } \\
\text { factors on implementation and } \\
\text { LCC }\end{array}$ \\
\hline (e) & $\begin{array}{l}\text { Verification of } \\
\text { implementation factors } \\
\text { impact rate results by } \\
\text { statistical significance }\end{array}$ & $\begin{array}{l}\text { Questionnaire data-Statistica } \\
\text { software }\end{array}$ & Kruskal-Wallis test & Statistical significance \\
\hline 7. & Hypothesis evaluation & & & \\
\hline
\end{tabular}

\subsection{Research Aim and Hypothesis}

The research focused on analyzing the implementation factors of ICT in the life cycle cost of buildings. Monitoring and analyzing construction costs in each phase of a construction project is the first step to managing and attempting to optimize these costs. A thorough analysis of research and studies has focused on the impact and implementation factors of using ICTs.

The research aim is to analyze the implementation factors of ICT in the life cycle costs of buildings and verify that investment costs represent the most critical implementation factor.

The primary research claims that information and communication technology play an important role in construction life cycle cost management based on study knowledge and research. One of the most significant advantages of using information and communication technology is a positive impact on reducing costs at every stage of a construction project's life cycle. In addition, key factors impact the implementation of information and communication technology in life cycle cost management. Based on this, the main hypothesis adopts this claim. 
Hypothesis statement: Investment costs are the most important ICT implementation factor in managing the buildings' life cycle costs.

This statement means that, in analyzing the impact ranking of factors, the factor investment costs will achieve the highest value and be ranked first. Based on this, a null hypothesis can be postulated and verified. This means that no implementation factor has a higher impact rate than investment costs. The investigated main or null hypothesis and its alternative have the following form:

Hypothesis 1. Investment costs are ranked first as the most important ICT implementation factor in managing the life cycle costs of buildings.

Hypothesis 0. Investment costs are not ranked first as the most important ICT implementation factor in managing the life cycle costs of buildings.

\subsection{Data Collection and Research Sample}

Data collection was carried out through an online questionnaire. The questionnaire was divided into several parts that were content related. The first part of the questionnaire focused on the characteristics of the respondents. This included information about the participant in the construction project; the size of the construction company (How many employees does your construction company have?); the work experience of the project manager (How long have you been working as a project manager?); the participation of foreign capital and know-how (Do you use only domestic capital and know-how?; Do you use foreign capital or know-how of another parent company?); construction project size and characteristic of buildings (How big is the construction project, based on which you assess the level of impact of information and communication technology in the context of the life cycle cost issue?).

The second part of the questionnaire dealt with direct questions on the perception of the implementation factors of using information and communication technology (Specify the information systems used in project management and planning life cycle cost management; Specify the extent and frequency of use of these technologies based on the scale provided). The next part focused on issues related to the impact on construction life cycle management and implementation factors of information and communication technology (based on the Likert scale, respondents defined their perception of selected implementation factors of using ICT for cost management in individual stages of a construction project; these data were based on real results of construction project costs (1-change up to $5 \%$, 2 -change from $6 \%$ to $10 \%, 3$ - change from $11 \%$ to $15 \%$, 4-change from $16 \%$ to $20 \%$, 5 -change over $21 \%$ ).

The third part of the questionnaire survey also included questions focused on using information and communication technologies and quantifying the impacts of the implementation of information and communication technologies on the life cycle cost. Respondents who stated that they use selected information technologies should also quantify the impact on the life cycle cost (as a percentage) and the degree of improvement in communication between participants in the construction project.

The list of implementation factors resulting from the use of ICT was compiled based on a thorough theoretical analysis of resources and research dealing with the implementation factors of ICT in the cost management of buildings [22-32]. Experts reviewed the long list of implementation factors in the field by interview. These were mainly project managers and financial managers in the field of cost management in the construction industry. These interviewed managers came from Slovak construction companies and investors. Based on a theoretical long list of ICT implementation factors, and consultation with project managers, a researched list of implementation factors was established.

Respondents answered the questions using an evaluation based on a 5-point Likert scale, where the value of 5 represented very significant and 1 represented not significant. Questions on some cost issues were filled in as nominal or relative indicators. The ques- 
tionnaire also contained a detailed explanation of the interpretation of the Likert scale's values, as mentioned in the previous paragraph.

The research involved respondents who represented the main participants in the construction project. These were most often significant contractors and sub-contractors, but also included investors and architects. Regarding job positions were concerned, among the suppliers were project managers and cost managers. Among architects, participants were often designers from design studios. The investor was represented through the finance department and financial managers. A more detailed specification of the research sample is shown in Table 4.

Table 4. Structure of research participants.

\begin{tabular}{lcc}
\hline Type of Enterprises $(\boldsymbol{n}=\mathbf{1 2 5})$ & Frequency & \% Share \\
\hline Participant of construction & & \\
project & 65 & 52.00 \\
Contractor & 21 & 16.80 \\
Sub-contractor & 14 & 11.20 \\
Investor & 25 & 20.00 \\
Designer & 40 & 32.00 \\
Enterprise size & 42 & 52.5 \\
Micro enterprises & 38 & 47.5 \\
Small enterprises & 5 & 4.00 \\
Medium-sized enterprises & 13 & \\
Large enterprises & 112 & 10.40 \\
Business funding origin & & \\
International private & 35 & \\
National private & 57 & 28.00 \\
Working experience in work & 23 & 45.60 \\
position & 10 & 18.40 \\
0-5 years & & 10.00 \\
6-10 years & & \\
11-20 years & years and more &
\end{tabular}

\subsection{Data Processing}

Data processing was performed based on verified statistical methods. This processing took place in the software environment of MS Excel and Statistica. The obtained data combined quantitative and qualitative data collection methods, using values of 1 to 5 based on the distribution of the Likert scale, were the basis for subsequent statistical processing. Based on a random selection of a research sample representing the real situation of the construction market, the statistical extremes were adjusted to ensure they did not distort the results.

The relative importance index (RII) was used to determine the quantification and significance of individual implementation factors resulting from the impact of the implementation process of information and communication technology on buildings' life cycle costs. This is a scientific method that is commonly used to determine rankings, often in construction surveys. RII is calculated using the following expression:

$$
\mathrm{RII}=\frac{\sum_{\mathrm{i}=1}^{5} \mathrm{w} \mathrm{Xi}}{\mathrm{A} \times \mathrm{N}}
$$

$\mathrm{RII}=$ relative importance index

$\mathrm{w}=$ weighting given to each benefit by respondents and it ranges from 1 to 5

$\mathrm{x}=$ frequency of the $\mathrm{i}$-th response given for each cause

$\mathrm{A}=$ highest weight (i.e., 5 in this case)

$\mathrm{N}=$ total number of participants

The ranking for each area is considered important to discuss construction life cycle cost management. Comparing and focusing on cost parameters is highly important in 
research. The implementation factors for each area did not reach the same ranking. It is essential to look at the key values and compare them in life cycle cost management. This means their significance in terms of individual stages of the construction project. The areas related to the research area of construction life cycle management were specified for total costs and costs associated with the construction project's management.

The significance of individual implementation factors can be assessed based on interval values, including specific measured values. According to Akadiri [44], five critical levels are transformed from RII values:

- $\operatorname{high}(\mathrm{H})(0.8 \leq \mathrm{RII} \leq 1)$,

- high-medium $(\mathrm{HM})(0.6 \leq \mathrm{RII} \leq 0.8)$,

- $\quad$ medium $(\mathrm{M})(0.4 \leq \mathrm{RII} \leq 0.6)$,

- $\quad$ medium-low (ML) $(0.2 \leq \mathrm{RII} \leq 0.4)$ and

- $\quad \operatorname{low}(\mathrm{L})(0 \leq \mathrm{RII} \leq 0.2)$.

This is crucial because these values can be clearly specified and directly classified based on a proven scientific method. The results in the form of rankings were compared with the intervals, and preliminary conclusions were drawn. In this case, it is necessary to also verify these results by statistical significance. Based on the research sample distribution, it was evaluated that it is best to perform this distribution using Kruskal-Wallis tests for a given type of data. The Kruskal-Wallis test was chosen for statistical testing. This test was chosen because the researchers worked with an ordinal variable. As the dependent variable was ordinally scaled, the Kruskal-Wallis test was required. Applying the given tests allowed determination of whether statements and assumptions examined by the current research were statistically significant.

The threshold for the use and impact of information technology (IT) and information systems (IS) was set at 3.5. This value was determined based on several sources, however, values above 3.5 are considered significant [45].

\subsection{Limitations of Research}

The implementation of research activities related to the examined issue uncovered several limitations. It should be considered whether these limitations could reduce the value of the results or change the research conclusions. At the outset, the current study focused on the perception of the research problems identified in the project manager's specific questions (i.e., one person evaluated the success of the project and answered the research questions for the whole project). These facts may raise questions about the subjective evaluation of this respondent. However, this was prevented by a detailed description using percentages for each research area and question. Based on real accounting data, the respondent (project manager) clearly defined the percentage to which his answer belongs in the Likert scale.

Another issue from the point of view of the correctness of the interpretation of the results and the comparison was the size of the companies participating in the research and establishing a condition to compare these results. The responses in the form of a Likert scale with a description of the values (relative indicator in percent) were determined for this purpose. Therefore, in cost perception in projects of different sizes, comparing absolute values was not possible, and a relative indicator appears to be the most relevant type of research data acquisition.

The research also took into account the number of forms information and communication technology used, but only at intervals. The use of information and communication technology was considered in all construction projects that pointed to 3 or more IS and IT. For comparison, however, the results may have been skewed according to the number of forms of information and communication technology used.

\section{Results and Discussion}

The use of ICTs has several advantages, which was also the statement of several respondents. However, as several also stated, the expectations and benefits of implementing 
ICTs should be greater than the factors (in many cases, the concerns) that hinder the implementation of the decision to implement ICT. This research sought to quantify and analyze these implementation factors focusing on cost optimization throughout the life cycle of the construction project and a positive impact on cost management during the life cycle of buildings. Experts in the field answered questions about these implementation factors. They tried to quantify the impact level of implementation factors on the Likert scale based on managing construction projects.

Based on the answers, the RII index was used to obtain the ranking of implementation factors resulting from thinking about ICT implementation in construction projects' cost management. The final ranking, which considers the entire life cycle of the construction project and buildings (i.e., pre-design and design stage, project stage, construction phase, and maintenance and use stage of the building, up to its liquidation) is given in detail in Table 5.

Table 5. Relative importance index of ICT implementation factors in life cycle cost management.

\begin{tabular}{|c|c|c|c|}
\hline Group of IFs & Implementation Factors (IFs) & RII & Ranking \\
\hline \multirow{3}{*}{ Economic factors } & Investment costs for ICTs & 0.879 & 1 \\
\hline & System maintenance costs during its lifetime & 0.758 & 5 \\
\hline & The need to recruit IT staff to manage ICTs & 0.735 & 7 \\
\hline \multirow{5}{*}{ Technical factors } & 4. Compatibility of software solutions & & \\
\hline & Functional possibilities of the system & 0.648 & 9 \\
\hline & 6. Knowledge of the use of ICT in the field & 0.357 & 16 \\
\hline & 7. System maintenance and service and the need to & 0.489 & 14 \\
\hline & $\begin{array}{l}\text { upgrade the system (administrative burden, } \\
\text { inspections, repairs) }\end{array}$ & 0.737 & 6 \\
\hline \multirow{5}{*}{ Personnel factors } & 8. User qualification (training and certificates) & 0.648 & 9 \\
\hline & 9. User experience (practical experience) & 0.567 & 13 \\
\hline & 10. Readiness and disinterest of users & 0.639 & 11 \\
\hline & 11. Ability to embrace innovation and change & 0.706 & 8 \\
\hline & 12. Management support & 0.778 & 4 \\
\hline \multirow{4}{*}{ Industry factors } & $\begin{array}{l}\text { 13. Fragmentation of the sector and integration } \\
\text { among participants in construction projects }\end{array}$ & 0.583 & 12 \\
\hline & 14. Legislative framework & 0.837 & 2 \\
\hline & 15. Level of competition in the use of ICT & 0.435 & 15 \\
\hline & $\begin{array}{l}\text { 16. Level of use of ICT by other participants in the } \\
\text { construction project. }\end{array}$ & 0.784 & 3 \\
\hline
\end{tabular}

Based on the ranking results, it can be stated that the most extensive relative importance index was achieved for the implementation factor "Investment Costs for ICTs", with a value of 0.879 , which falls in the interval $(\mathrm{H})(0.8 \leq \mathrm{RII} \leq 1)$, i.e., a high value. The "legislative framework" achieved a similar value and the same order in the ranking. These two implementation factors achieved a relative importance index higher than 0.8 and are therefore considered significant. These results suggest a research statement and consideration of the most critical implementation factor. However, for a correct evaluation and conclusion, this result must be evaluated by statistical tests that confirm its statistical significance. In addition, however, the research also yielded other quantitative and qualitative results that need to be discussed within the topic.

Significant results, according to the ranking, also included the following implementation factors (factors that reached 0.6 and higher): level of use of ICT by other participants in the construction project; management support; system maintenance costs during its lifetime; system maintenance and service and the need to upgrade the system; the need to recruit IT staff to manage ICTs; ability to embrace innovation and change; compatibility of software solutions; user qualification (training and certificates); and readiness and disinterest of users. Of a total of 16 examined implementation factors, up to $12(75 \%)$ can be considered significant based on ranking. All examined economic factors were identified as significant implementation factors. These fall in the interval of $(0.6 \leq \mathrm{RII} \leq 0.8)$, which can 
be considered as medium-high significance. This again points to the trend that investment costs and other types of costs associated with ICT implementation represent a serious implementation factor.

It is essential that these findings and the main research hypothesis are confirmed using the Kruskal-Wallis test. An overview of groups of factors shows that the most important are economic factors. Personal factors are also significant. Overall, the setting of people (employees) to accept change, and accept innovation and their skills and knowledge in the IT field, significantly affect the implementation of ICT in the cycle cost management of construction and construction projects. Based on the Likert scale and Kruskal-Wallis testing, an infographic was constructed that highlights the importance of individual factors for specific groups and provides information about the arithmetic mean for individual implementation groups (Figure 1).

It is possible to discuss why experts and managers of construction projects have quantified and determined such a ranking of these implementation factors. These results should be compared with the research already carried out in the field of ICT implementation factors in the context of managing life cycle costs of buildings. The research results also confirm the research conclusions of [22-29], in which the investment cost was a significant implementation factor. This result and comparison point to one of the phases of a construction project in the context of cost management. The research results point to a relatively high degree of implementation factors in life cycle cost management.

An important view of the results is presented in Figure 1, in which the degree of importance of the implementation factor is quantified. The investment costs reached the highest value, and the given rate was 4.395 , which represents very high importance from the point of view of ICT implementation. Regarding the degree of saving resulting from the use of ICT, which this research investigates, it can be stated that the turning point at which ICT will cover investment costs, should be in the 6th to 10th construction project. This clearly depends on other factors such as the size of the projects. However, consideration must also be given to operating costs, which extend this period. In terms of the most significant impact on implementing ICT for life cycle cost management, it is possible to define a significant level (3.954) of economic factors. Thus, in addition to the investment costs, the operating costs and the costs for the employees who will manage the selected technologies must be included. The research also included questions focused on using information and communication technologies and their impact on LCC. This impact was mentioned by several respondents, based on which the Kruskal-Wallis test was also carried out to determine if results were statistically significant. Due to the implementation and use of ICT, the value of cost savings was $10 \%$ to $15 \%$.

The use of ICTs can increase efficiency, which has a limited impact on achieving optimization or a reduction in costs, and costs in terms of the entire life cycle of the construction. Monitoring the impacts on life cycle cost management is the more complex subject of this research. During interviews or in response to additional questions, several experts indicated that ICT leads to better cost management if communication and sharing of necessary information is faster. This also proved to be significant at every stage of the life cycle of a construction project. Here, however, it must be noted that although this rate was different in the individual phases of the construction cycle, it always reached the level of at least medium or medium-high based on the empirical method. The details of these differences discussed in more detail later. Based on the RII, the ranking and intervals were determined, and indicated the degrees of importance. However, from a statistical point of view, these values should be verified. Therefore, based on the Likert scale and data on the frequency of responses with specific values, a table of importance or the so-called importance rate (IR), with values from 1 to 5 , was constructed. This is the average value of all respondents values, which is the important frequency of responses. This importance index shows the frequency of utilization in similar cases and studies globally. The results are mentioned in more detail in Table 6, which shows the value of the Kruskal-Wallis test for the statistical significance level (Table 5). 

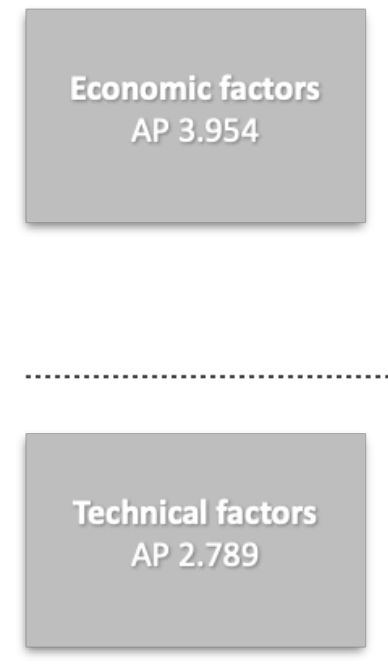

Personal factors AP 3.338

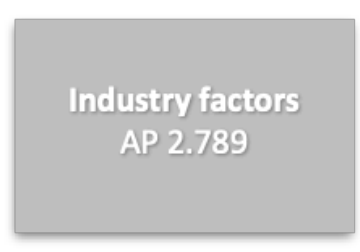

Investment costs for ICTs $\mathbf{4 . 3 9 5}$

System maintenance costs during its lifetime $\mathbf{3 . 7 9 0}$

The need to recruit IT staff to manage ICTs $\mathbf{3 . 6 7 5}$

Compatibility of software solutions $\mathbf{3 . 2 4 0}$

Functional possibilities of the system 1.785

Knowledge of the use of ICT in the field $\mathbf{2 . 4 4 5}$

System maintenance and service and the need to upgrade the system $\mathbf{3 . 6 8 5}$

User qualification (training and certificates) $\mathbf{3 . 2 4 0}$

User experience (practical experience) $\mathbf{2 . 8 3 5}$

Readiness and disinterest of users $\mathbf{3 . 1 9 5}$

Ability to embrace innovation and change $\mathbf{3 . 5 3 0}$

Management support $\mathbf{3 . 8 9 0}$

Compatibility of software solutions $\mathbf{3 . 2 4 0}$

Functional possibilities of the system 1.785

Knowledge of the use of ICT in the field $\mathbf{2 . 4 4 5}$

System maintenance and service and the need to upgrade the system $\mathbf{3 . 6 8 5}$

Figure 1. Implementation factor groups and impact rates. 
Table 6. Hypothesis results and Kruskal-Wallis ANOVA results.

\begin{tabular}{lccc}
\hline \multicolumn{1}{c}{ Hypothesis } & Parameter & K-W Anova (p) & Rejection \\
\hline $\begin{array}{l}\mathrm{H}_{1} \text { : Investment costs are ranked first in } \\
\text { the most important ICT implementation } \\
\begin{array}{l}\text { factors in managing the life cycle costs } \\
\text { of buildings. }\end{array}\end{array}$ & RII Ranking & 0.0476 & accepted \\
$\begin{array}{l}\mathrm{H}_{0} \text { : Investment costs are not ranked first } \\
\begin{array}{l}\text { in the most important ICT } \\
\text { implementation factors in managing the }\end{array}\end{array}$ & RII Ranking & & rejected \\
life cycle costs of buildings & & & \\
\hline
\end{tabular}

From the Kruskal-Wallis ANOVA based on ranking, the variable "ICT implementation factors in life cycle cost management" achieved a $p$-value of 0.0476 , which has significant statistical significance. The number of valid responses was 125 for each factor (see Table 5).

Table 5 describes the Kruskal-Wallis test to examine the statistical significance of selected factors' impact on ICT implementation. Table 5 also describes the decision and evaluation of the scientific hypothesis based on the Kruskal-Wallis ANOVA. Thus, the achieved $p$-value was 0.0476 . This indicates that the statistical implementation factors confirmed the statistical significance. That is, at the level of probability $\alpha=0.05$, we can reject $\mathrm{H}_{0}$ : investment costs are not ranked first in the most important ICT implementation factors in managing the life cycle costs of building, and thus accept the hypothesis $\mathrm{H}_{1}$ : investment costs are ranked first in the most important ICT implementation factors in managing the life cycle costs of buildings. Thus, it follows that investment costs represent the most important implementation factor influencing the implementation and use of ICT in the life cycle cost management of buildings.

\section{Conclusions}

It is necessary to examine the issue of implementation factors of ICT adoption in life cycle cost management and, in particular, to quantify and manage the actual cost of a construction project during its entire life cycle. Several studies point to factors that may influence the implementation of ICT in life cycle cost management. This research sought to verify these claims. The assumption was that investment costs represent the most critical implementation factor of ICT in life cycle cost management. This statement can be accepted based on the empirical methods performed. Based on a selected sample of respondents and projects, it was determined that investment costs are the most critical implementation factor. Several studies have confirmed the benefits of using ICT in life cycle cost management of buildings. Therefore, examining the factors influencing this implementation was highly important, and the research findings are essential for practitioners. Simultaneously, the research noted other essential implementation factors of ICT in life cycle cost management. These are the level of use of ICT by other participants in the construction project; management support; system maintenance costs during its lifetime; system maintenance and service and the need to upgrade the system; the need to recruit IT staff to manage ICTs; ability to embrace innovation and change; compatibility of software solutions; user qualifications (training and certificates); and readiness and disinterest of users and legislative framework. The research also highlighted the importance of all economic factors related to the implementation of ICT in life cycle cost management. Maintenance costs and the costs associated with recruiting new staff to the IT department greatly influence the decision to implement ICT for life cycle cost management.

This issue is closely linked to the issue of implementation benefits. This represents another research gap that this research should address. The extension of this scientific and practical issue should be addressed using the same research sample, which would allow a confrontation with the results of this study. The direct benefits of implementing ICT in life cycle cost management can contribute to the growth of ICT implementation in construction. 
This research confirms the claims of previous studies $[12,16]$. These previous studies note the importance of implementing information and communication technologies for life cycle cost management. The positive impact on cost financing was also confirmed. As also mentioned in a previous study [18], one of the main factors is investment costs. Another study [18] also found that this research has not substantiated that operating costs exceed investment costs, and that this is a larger implementation factor.

In contrast, research has also examined the effects of information and communication technologies, and a positive impact of the use of information and communication technologies was found, as stated in the study [20].

The most important research results can be summarized as:

- $\quad$ high investment costs are the most critical implementation factor,

- $\quad$ operating costs are also a critical implementation factor for the adoption of ICT, but this is not the most important, as some studies claim;

- the survey showed that the use of information and communication technologies has the effect of reducing life cycle cost management costs, and this result has also been quantified at $10 \%$ to $15 \%$ of costs;

- implementation has improved communication between research participants;

- $\quad$ research quantified the importance of specific implementation factors for adopting ICT in life cycle cost management (this important information for practice has not yet been mentioned in any research).

Knowledge of implementation factors in practice also means focusing on specific processes that can contribute to better implementation of ICT in construction. It can also challenge the views and support of management, which can positively affect the industry's development.

Author Contributions: Conceptualization, P.M. and T.M.; methodology, T.M.; software, T.M.; validation, T.M., A.B. and M.B.; formal analysis, M.S.; investigation, T.M., A.B. and M.B.; resources, T.M., A.B. and M.B.; data curation, T.M., A.B.; writing—original draft preparation, T.M., M.S., P.M.; writing—review and editing, P.M.; visualization, T.M.; supervision, P.M.; project administration, T.M.; funding acquisition, P.M. All authors have read and agreed to the published version of the manuscript.

Funding: This work was supported by the Slovak Research and Development Agency under the contract no. APVV-17-0549. The paper presents partial research results of project VEGA 1/0828/17 "Research and application of knowledge-based systems for modelling cost and economic parameters in Building Information Modelling". The paper also presents partial research results of project KEGA 059TUKE-4/2019 "M-learning tool for intelligent modeling of building site parameters in a mixed reality environment".

Institutional Review Board Statement: Not applicable.

Informed Consent Statement: Not applicable.

Data Availability Statement: All research activities have been carried out in accordance with the MDPI Ethics and there is no obstacle on our part.

Acknowledgments: This work was supported by the Slovak Research and Development Agency under the contract no. APVV-17-0549. Paper presents a partial research results of project VEGA 1/0828/17 "Research and application of knowledge-based systems for modelling cost and economic parameters in Building Information Modelling". The paper presents a partial research results of project KEGA 059TUKE-4/2019 "M-learning tool for intelligent modeling of building site parameters in a mixed reality environment".

Conflicts of Interest: The authors declare no conflict of interest.

\section{References}

1. Hromádka, V.; Korytárová, J.; Vítková, E.; Seelman, H.; Funk, T. New aspects of socioeconomic assessment of the railway infrastructure project life cycle. Appl. Sci. 2020, 10, 7355. [CrossRef]

2. Biolek, V.; Hanák, T. LCC Estimation Model: A Construction Material Perspective. Buildings 2019, 9, 182. [CrossRef] 
3. Zabielski, J.; Zabielska, I. Life Cycle of a Building (LCC) in the Investment Process-Case Study. In Proceedings of the Baltic Geodetic Congress, BGC-Geomatics, Olsztyn, Poland, 21-23 June 2018; pp. 254-259.

4. Chen, C.; Tang, L. BIM-based integrated management workflow design for schedule and cost $\mathrm{T}$ planning of building fabric maintenance. Autom. Constr. 2020, 107, 1-12. [CrossRef]

5. Knezevic, M.; Cvetkovska, M.; Hanák, T.; Braganca, L.; Soltesz, A. Artificial Neural Networks and Fuzzy Neural Networks for Solving Civil Engineering Problems. Complexity 2018, 1-2-2. [CrossRef]

6. De Haes, H.A.U.; Rooijen, M.V. Life Cycle Approaches: The Road from Analysis to Practice; UNEP/SETAC Life Cycle Initiative: Paris, France, 2005.

7. Westkämper, E.; Alting, A. Life Cycle Management and Assessment: Approaches and Visions Towards. Sustain. Manuf. Cirp Ann. 2009, 49, 501-526. [CrossRef]

8. Bey, N. Life Cycle Management. In Life Cycle Assessment: Theory and Practice; Springer: Berlin/Heidelberg, Germany, 2018.

9. Kambanou, M.L. Life Cycle Costing: Understanding How It Is Practised and Its Relationship to Life Cycle Management-A Case Study. Sustainability 2020, 12, 3252. [CrossRef]

10. Grieves, M. CIM data, Product lifecycle management-Empowering the future of business. Technic. Repet. 2002, 2, 1-21.

11. Corallo, A.; Latino, M.E.; Lazoi, M.; Verardi, S. Defining Product Lifecycle Management: A Journey across Features, Definitions, and Concepts. Int. Sch. Res. Not. 2013, 2013, 1-10. [CrossRef]

12. Kim, G.T.; KIM, K.T.; Lee, D.H.; Han, C.H.; Kim, H.B.; Jun, J.T. Development of a life cycle cost estimate system for structures of light rail transit infrastructure. Autom. Constr. 2010, 19, 308-325. [CrossRef]

13. Hanák, T.; Marović, I.; Aigel, P. Perception of Residential Environment in Cities: A Comparative Study. Procedia Eng. 2015, 117, 495-501. [CrossRef]

14. Fantozzi, F.; Gargari, C.; Rovai, M.; Salvadori, G. Energy Upgrading of Residential Building Stock: Use of Life Cycle Cost Analysis to Assess Interventions on Social Housing in Italy. Sustainability 2019, 11, 1452. [CrossRef]

15. De Soto, B.G.; Augustí-Juan, I.; Hunhevicz, J.; Joss, S.; Graser, K.; Habert, G.; Adey, B.T. Productivity of digital fabrication in construction: Cost and time analysis of a robotically built wall. Autom. Constr. 2018, 92, 297-311. [CrossRef]

16. Plebankiewicz, E.; Wieczorek, D. Prediction of cost overrun risk in construction projects. Sustanability 2020, 12, 9431. [CrossRef]

17. Korytarova, J.; Hromadka, V. Building life cycle economic impacts. In Proceedings of the International Conference on Management and Service Science, Wuhan, China, 24-26 August 2010.

18. Korytárová, J.; Hanák, T.; Kozik, R.; Radziszewska-Zielina, E. Exploring the contractors' qualification process in public works contracts. Procedia Eng. 2015, 123, 276-283. [CrossRef]

19. Plebankiewicz, E.; Wieczorek, D. Adaptation of a cost overrun risk prediction model to the type of construction facility. Symmetry 2020, 12, 1739. [CrossRef]

20. Plebankiewicz, E.; Malara, J. Analysis of defects in residential buildings reported during the warranty period. Appl. Sci. 2020, 10, 6123. [CrossRef]

21. Vasista, T.G.; Abone, A. Benefits, Barriers and Applications of Information Communication Technology in Construction Industry: A Contemporary Study. Int. J. Eng. Technol. 2018, 7, 492-499. [CrossRef]

22. Hasan, A.; Ahn, S.; Rameezdeen, R.; Baroudi, B. Empirical Study on Implications of Mobile ICT Use for Construction Project Management. J. Manag.Eng. 2019, 35, 04019029. [CrossRef]

23. Sargent, K.; Hyland, P.; Sawang, S. Factors influencing the adoption of information technology in a construction business. Australas. J. Constr. Econ. Build. 2012, 12, 72-86. [CrossRef]

24. Wang, G.; Lu, H.; Gao, X. Understanding Behavioral Logic of Information and Communication Technology Adoption in Smalland Medium-Sized Construction Enterprises: Empirical Study from China. J. Manag. Eng. 2020, 36, 1-16. [CrossRef]

25. Sekou, A.E. Promoting the Use of ICT in the Construction Industry, Assessing the Factors Hindering Usage by Building Constractors in Ghana. Ph.D. Thesis, Kwame Nkrumah University, Kumasi, Ghana, September 2012.

26. Linderoth, H.C.J.; Jacobsson, M. Understanding adoption and use of ICT in construction projects through the lens of context, actors and technology. In Proceedings of the International Conference on Information Technology in Construction, CIB W78, Santiago, Chile, 15-17 July 2008.

27. Wigforss, O.; Lofgren, A. Rethinking communication in construction. ITcon 2007, 12, 337-345.

28. Woksepp, S.; Olofsson, T. An evaluation model for ICT investments in constriction project. ITconstruction 2009, 13, $343-361$.

29. Lu, H.; Pishdad-Bozorgi, P.; Wang, G.; Xue, Y.; Tan, D. ICT Implementation of Small- and Medium-Sized Construction Enterprises: Organizational Characteristics, Driving Forces, and Value Perceptions. Sustainability 2019, 11, 3441. [CrossRef]

30. Sepasgozaar, S.M.E.; Shirowzhan, S.; Wang, C. A scanner technology acceptance model for construction projects. Procedia Eng. 2017, 180, 1237-1246. [CrossRef]

31. Wang, G.B.; Cao, D.P.; Chong, D. Investigation to factors affecting IT implementation in Chinese construction projects. In Proceedings of the 4th Conference on Systems Science, Management Science and Systems Dynamics, New York, NY, USA, 10-11 April 2011; Volume 3, pp. 1-13.

32. Mahamadu, A.M.; Mahdjoubi, L.; Booth, C.A. Determinants of building information modelling (BIM) acceptance for supplier integration: A conceptual model. In Proceedings of the 30th Annual ARCOM Conference; Portsmouth, UK, 1-3 September 2014, Association of Researchers in Construction Management; pp. 723-732. 
33. Soetanto, R.; Dainty, A.R.J.; Price, A.D.F.; Glass, J. A framework for investigating human issues associated with the implementation of new ICT systems in construction organizations. Innov. Dev. Archit. Eng. Constr. 2003, 2, 121-130.

34. Tetik, M.; Peltokorpi, A.; Seppänen, O.; Holmstrom, J. Direct digital construction: Technology-based operations management T practice for continuous improvement of construction industry performance. Autom. Constr. 2019, 107, 1-13. [CrossRef]

35. Love, P.E.D.; Matthews, J. The how of benefits management for digital technology: From engineering to asset management. Autom. Constr. 2019, 107, 1-15. [CrossRef]

36. Flanagan, R.; Marsh, L. Measuring the costs and benefits of information technology in construction. Eng. Constr. Archit. Manag. 2000, 7, 423-435. [CrossRef]

37. Khayyat, N.T. Effects of information technology on cost, quality and efficiency in provision of public services. In Information and Communication Technologies; Nova Science Publishers, Inc.: Hauppauge, NY, USA, 2010.

38. Pérez-López, R.J.; Olguín-Tiznado, J.E.; García-Alcaraz, J.L.; Camargo-Wilson, C.; López-Barreras, J.A. The Role of Planning and Implementation of ICT in Operational Benefits. Sustainability 2018, 10, 2261. [CrossRef]

39. Koskela, L.J.; Kazi, A.S. Information Technology in Construction: How to Realise the Benefits? Information Science Publishing: Manchester, UK, 2003.

40. Lambrecht, J.F.; Vestergaard, F.; Karlshøj, J.; Hauch, P.; Mouritsen, J. Measuring the effects of using ICT/BIM in construction projects. In Proceedings of the 33rd CIB W78 Conference 2016, Brisbane, Australia, 31 October-2 November 2016.

41. Sheng, D.; Ding, L.; Zhong, B.; Love, P.E.D.; Luo, H.; Chen, J. Construction quality information management with blockchains. Autom. Constr. 2020, 120,1-16. [CrossRef]

42. Heigermoser, D.; Garcia de Soto, B.; Sidney Abbott, E.L.; Chua, D.K.H. BIM-based Last Planner System tool for improving construction project management. Autom. Constr. 2019, 104, 246-254. [CrossRef]

43. Chi, C.; Yang, L. Measurement of ICT impact. J. Adv. Commun. Syst. Technol. 2011, 3, 1-11.

44. Akadiri, P.O.; Olomolaiye; Chinyio, E.A. Multi-criteria evaluation model for the selection of sustainable materials for building projects. Autom. Constr. 2013, 30, 113-125. [CrossRef]

45. Mutesi, E.T.; Kyakula, M. Application of ICT in the construction industry in Kampala. In Proceedings of the Second International Conference on Advances in Engineering and Technology, Kampala, Uganda, 31 January-2 February 2011; pp. $263-269$. 